\title{
Research on Communicative Ability Training Mode under Network Business English
}

\author{
Jing Zheng ${ }^{1, a}$ \\ ${ }^{1}$ Jiangxi Science \& Technology Normal University, Nanchang, Jiangxi, 330013 \\ a email
}

Keywords: Network Environment, Business English, Communicative Competence, Training Mode

\begin{abstract}
With the progress and development of contemporary science and technology, the application of multimedia computers and networks are increasingly being used, the traditional English teaching model also suffered a serious impact, context, digitization, personalization and intelligent networking and new business English communicative ability and training mode gradually formed, the traditional English teaching mode in classroom books education is undergoing major reform and innovation. This paper explores the perspective of promoting the role and value of the Internet age on the current business English language teaching brought on departure, and on this basis to explore the network environment Business English Communication Capacity Building Model, hope to nurture more social development and more comprehensive business English communicative talents.
\end{abstract}

\section{Introduction}

As in recent years, the rapid development of science and technology, people gradually into the information network era, the use of multimedia computers are increasingly popular, but also to many of our industries and fields to bring a significant role in promoting, in particular, It is the country's education sector. With the advent of the Internet age, to promote the traditional teaching model suffered a serious impact, it gradually began to reform and innovation. English as a world language of communication, its role is self-evident. As China's market economy, more and more English in our concern, as many people have their own native language to learn a second. With the way the Internet age, business English language teaching has also brought a great role in promoting extent. Therefore, only a combination of the current Internet age, timely reform the traditional teaching model, in order to build a new business English communication ability and training mode.

\section{The Impetus for Business English Language Teaching on the Internet Age}

Public page in Internet and digital libraries, have a lot of business English language learning resources to be hearing a lot of information and relevant information available to business English learners, all forms of electronic documents in it's business English language teaching information and learning materials can be downloaded for free [1]. Teachers and students on the campus network to share those resources and transport, allowing teachers and students in teaching and research work is effectively promoted. So, in some ways speaking, do not see the network is a marginal sea of information, business English language teaching can freely choose where, and never "dry."

The aid of computer software to random selection of text, sound and image, while it provides communication locale is also more practical, realistic. The teacher can voice multimedia computer classroom, a student and any separate exchange, by means of a small camera also can be done on both sides of the mouth observed in detail. In Internet and online can be anyone willing to communicate with you to communicate with people, but also no regional restrictions, this interactive exchange of business English teaching has a very big help. In the traditional business English language teaching, teaching teaching method focuses mostly memories, so that students will combine their pronunciation and spelling of words to summarize, thus recorded in his notebook, and continue to carry out this review. In extracurricular reading unfamiliar words and sentences 
were continuing to draw on, and recorded in a notebook, so that their Business English vocabulary increased. There are also some idioms and fixed with, special attention must be done. But also some Chinese and have a large difference or more typical and unintelligible sentences were recorded in a notebook. With the advent of the Internet age, teachers can design or by means of the creation of multimedia animation context, to make the traditional rote teaching methods can be changed by clicking on the screen way for a number of presentations can be achieved and, thus, allow teachers conducted business English language teaching more relaxed environment, pleasant [2]. Moreover, the network can also be carried out by means of various means word memory, such as fast memory, select Chinese or English definitions, dictation, spelling exercises, and games. So that the traditional boring boring word back gradually become fun, relaxed, and this is a job for any teaching methods are difficult to achieve.

Through the use of modern computer information network, allowing digital libraries and various information databases at any time and place, for people to self-knowledge required to learn, but also to implement lifelong education. Especially in the network business English, business English and even the actual development of the same language. For example: can be very easy to understand newspapers and magazines of the day, to keep abreast of new vocabulary to do, such as vocabulary $9 \cdot 11$ of September 11; terrorists vocabulary Evil Doers, all of the time with the outbreak of terror gradually the spread, and the first time appeared on the Internet. In addition, the spread of new words but also by means of the network has been a media platform, whether it is in that part of the world, as long as there is a network, it is possible to raise awareness of the latest events.

\section{Construction Analysis of Business English Communicative Ability Mode}

This teaching model is based on the Internet to establish a network teaching platform, appropriate teaching resources stored on the remote host, by means of open and has a wealth of teaching resources has the characteristics of Internet network to conduct business in English Language Teaching. This model allows students to learn initiative and enthusiasm to get fully aroused, the body position to make the process of teaching students are effectively represented [3]. Students can combine their actual situation to choose the most appropriate learning content, teachers are able to bind to the level differences between students of the corresponding request, and let individualized teaching principles are effectively show. Moreover, the teaching requirements are not subject to the limitations of time and space and other factors, to promote distance learning can be easier to achieve. Besides, this teaching model also has a certain openness that allows each student's desktop are implemented as a class, which is more fit and full of lifelong education and teaching principles. Moreover, rich Internet online teaching resources can be more convenient to use and, thus, allow the completion of the purpose of teaching can be more easily achieved.

This teaching model is mainly in schools by means of LAN based teaching platform to build, use of multimedia teaching network software system to complete the teaching objectives. The biggest advantage of this model is that online teaching allows teachers to classroom content and processes to achieve effective control, so that the teachers for their management has been strengthened. By means of a high transmission speed internal campus LAN has, allows multimedia transmission, real-time communication between teachers and students and other functions can be effectively realized. Moreover, the teacher can control multimedia teaching network software reasonable use, make a lot of classroom teaching behaviors, such as group teaching, electronic show of hands and the mutual exchange counseling, can be effectively realized. In addition, with respect to the Internet network using the high cost, the use of campus local area network teaching platform to create a lower cost, and has a very high network security.

In the development of modern, innovative network technology enables the shackles of traditional teaching model to break, will be student-centered teaching model to build out the network environment so that teaching resources and learning resource advantages into real, effective extension of student learning space and learning diversified [4]. Business-related English teachers should make full use of resources, expanding the network platform, television broadcasting, courseware and other learning promote business case column and business people more vivid, 
specific, so as to bring more business students knowledge of English, prompting students not only learn to rely on classroom instruction, to enable them to achieve self-learning, knowledge is becoming active builders.

\section{Conclusion}

In summary, the purpose of teaching business English major is to cultivate students' communicative competence in English in international business environment. With the constant improvement and innovation of the modern growing computer network system, to promote modern business English teaching environment has been significantly improved, to promote a more diversified business English teaching methods. Thus, breaking the traditional teaching model, highlighting the dominant position of students, to promote business English teaching resources become more enriched, so in order for business English teaching purposes can be achieved.

\section{Acknowledgements}

Fund Project: Jiangxi Social Science "12th Five-Year" (2014) Planning Project <Theoretical Research and Practice of Business English 5C Target Teaching Principle>, project number: $14 Y Y 16$.

\section{References}

[1] Wang Ling. culture based on language learners' communicative competence network teaching platform for research and analysis - A Case Study of Business English vocabulary learning [J]. Communication of Vocational Education, 2015,02: 11-14.

[2] Liu Liyun, Yang Jinfeng, Jing Chunyan. marketing professionals in international communication skills Training mode - Based Practice Business Communication English Course [J]. Higher Education Forum, 2012,02: 40-42.

[3] Zhuang Chaiyong. training mode Intercultural Communication Competence and innovative approaches - Taking Business English Teaching as an Example [J]. Jiannan literature (classical Jiaoyuan), 2012,03: 318-319.

[4] Huang Wen. based Business English Communicative Ability work environment - Analysis of BEC Speaking Test [J]. Modern communication, 2011,11 Discourse Management and Strategic angle: 44-45. 